\title{
Morphological Abnormalities of the Terminal Neuromuscular Apparatus in Recent Juvenile Diabetes
}

\author{
Edith Reske-Nielsen, Gunnar Gregtrist, Aage Harmsen and Knud Lundbaek
}

\begin{abstract}
Department of Neuropathology, Department $G$ of Neurosurgery and Second Clinic of Internal Medicine, Kommunehospitalet, Aarhus University School of Medicine, Aarhus, Denmark
\end{abstract}

Received: September 11, 1969

\begin{abstract}
Summary. Muscle biopsies from eight cases of acute juvenile diabetes (a few weeks after the beginning of the disease) revealed well marked degenerative changes combined with vigorous regeneration of the terminal neuromuscular apparatus. This observation is in accordance with previous demonstrations of neurophysiological disturbances at this early stage of diabetes.
\end{abstract}

Anomalies morphologiques de l'appareil neuro-musculaire terminal dans le diabéte juvénile récent.

Résumé. Dans huit cas de diabète juvénile aigu (quelques semaines après le début de la maladie) des biopsies musculaires ont révélé des modifications dégénératives bien marquées, associées à une puissante régénération de l'appareil neuro-musculaire terminal. Cette observation est en accord avec les démonstrations précédentes de troubles neurophysiologiques à ce stade précoce du diabète.

Morphologische Anomalien der neuromuskulären Endplatte bei frisch entdeckten juvenilen Diabetikern

Zusammenfassung. Muskelbiopsien von 8 Patienten mit akutem juvenilem Diabetes (einige Wochen nach Krankheitsausbruch) zeigten ausgeprägte degenerative Veränderungen mit kräftigen Regenerationserscheinungen an der neuromuskulären Endplatte. Diese Befunde stimmen mit früher mitgeteilten Beobachtungen neurophysiologischer Störungen dieses Frühstadiums des Diabetes überein.

Key-words: Recent juvenile diabetes, neuropathy, motor endplates, muscle biopsy, neurogenic atrophy, intramuscular nervous system, electromyography, vibration sense, motor conduction velocity.
Symptoms and signs of clinical neuropathy in juvenile diabetics are often found after many years of diabetes, but are very unusual at the beginning of the disease. In long-term diabeties the clinical findings are well correlated to the histological abnormalities of the peripheral nerves. Some degree of microangiopathy of the vasa nervorum is found in many of these patients, and may contribute to the clinical picture (Fagerberg, 1959, Reske-Nielsen and Lundbæk, 1968).

One of us (Gregersen, 1967, 1968a, b, c, d) has demonstrated recently that at the very beginning of juvenile diabetes the function of the peripheral nerves is already altered, and also that this abnormality is reversible by normalization of the blood sugar. At the time when neurophysiological studies reveal these abnormalities, no symptoms and no signs of peripheral nerve disease are found by ordinary clinical examination.

Another reversible neurological phenomenon in diabetes mellitus, the abnormal vibratory perception during ischaemia, was demonstrated earlier by Steiness (1961).

Very little information is available about the pathology of the peripheral nervous system in acute, recent juvenile diabetes. In older literature, three young patients are described who died of coma a few months after the onset of diabetes, and in whom degeneration of the myelin sheaths of the peripheral nerves was observed (Auché, 1890; Fraser and Bruce, 1896; Marinesco, 1903). Fagerberg's study (1959) includes 2 patients less than 30 years old with duration of diabetes of one and two years. None of these showed pathological changes of the peripheral nerves. On the other hand, Thomas and Lascelles (1966) observed segmental loss of the myelin sheath in a 26 year old man with poorly regulated diabetes of three years' duration. No information is available about the terminal neuromuscular apparatus in recent juvenile diabetes.

The following is a report of a study of this most peripheral part of the nervous system in 9 juvenile diabetics, demonstrating that severe abnormalities are present right at the start of the disease.

\section{Patients and Methods}

The series consists of nine juvenile diabeties aged 16 to 32 years (Table 1). Except for patient No. 6, whose diabetes was discovered accidentally, all the patients had classic juvenile diabetes mellitus of short and well-defined duration. Patient No. 1 was started on insulin at the onset of the disease six months earlier, but the treatment was stopped again after six weeks when complete remission accurred. In three of the patients (No. 2, 8 and 9) ketosis was so severe at admission that insulin treatment was started immediately. The biopsy was performed one to two weeks later. The other five patients had not yet been put on treatment at the time of biopsy. 
All the patients, except No. 8 and 9 , were in reasonably good general condition and were up and about. None of them had retinopathy, proteinuria or loss of sensitivity and deep reflexes.

\section{Results}

The results obtained are seen in Table 2. They are indicated as in the corresponding table of the foregoing

Table 1 : Clinical and neurophysiological data

\begin{tabular}{|c|c|c|c|c|c|c|c|c|}
\hline $\begin{array}{l}\text { Pationt } \\
\text { No. }\end{array}$ & Biopsy No. & Age & $\begin{array}{l}\text { Acute symp- } \\
\text { toms of dia- } \\
\text { betes, weeks }\end{array}$ & $\begin{array}{l}\text { Fasting blood- } \\
\text { sugar at admis- } \\
\text { sion, } \mathrm{mg} \%\end{array}$ & Ketonuria & $\begin{array}{l}\text { MCV in pero- } \\
\text { neal nerve, } \\
\mathrm{m} / \mathrm{s}\end{array}$ & $\begin{array}{l}\text { Vibr. percept. } \\
\text { threshold, volts }\end{array}$ & $\begin{array}{l}\text { EMG, } \\
\text { normal or } \\
\text { path. }\end{array}$ \\
\hline 1 & 7816 & 29 & 26 & 272 & $\div$ & & 11 & \\
\hline 2 & 8159 & 30 & 3 & 303 & + & & 11 & \\
\hline 3 & 8510 & 21 & 3 & 246 & + & 45 & 8 & \\
\hline 4 & 8625 & 32 & 3 & 350 & $\div$ & 46 & 10 & \\
\hline 5 & 9182 & 20 & 8 & 187 & + & 48 & 16 & $\mathbf{N}$ \\
\hline 6 & 9419 & 18 & no sympt. & 228 & $\div$ & 44 & 11 & $\overrightarrow{\mathrm{P}}$ \\
\hline 7 & 9980 & 16 & 10 & 242 & $\div$ & 50 & 11 & \\
\hline 8 & 10110 & 20 & 4 & 608 & + & 47 & 10 & $\mathrm{P}$ \\
\hline 9 & 10127 & 16 & 4 & 490 & + & 41 & 6 & $\mathbf{N}$ \\
\hline
\end{tabular}

Vibration perception was measured on the great toe with a thesiometer in all the patients, and motor nerve conduction velocity of the peroneal nerve was determined in seven of them. Electromyography was performed in four patients.

Muscle biopsies were removed from nine patients, four from the short peroneal muscle, five from the anterior tibial muscle. The localization of the end plates of these muscles is well defined.

One piece of the biopsy was stained by ordinary histological methods and another by Koelle's choli- paper on long-term diabetes (Reske-Nielsen. et al., 1969).

The ordinary muscle biopsy revealed in five patients signs of incipient neurogenic atrophy - demonstrated by slender fibres, increased number of nuclei beneath the sarcolemma, and fat cells between the muscle fibres. Four patients showed clear - cut neurogenic atrophy (Fig. 1). Hyaline and ringed fibres were seen in a few cases. All the vessels looked normal.

The staining by Koelle's method showed slight changes in half of the patients. The number of the subneural

Table 2. Histological findings in muscle biopsies. Patients No. 1, 3, and 4 were biopsied twice: before treatment and after 13-25 days of insulin treatment

\begin{tabular}{|c|c|c|c|c|c|c|c|c|c|c|c|}
\hline $\begin{array}{l}\text { Patient } \\
\text { No. }\end{array}$ & Initials & $\begin{array}{l}\text { Biopsy } \\
\text { No. }\end{array}$ & $\begin{array}{l}\text { Neurogenic } \\
\text { atrophy of } \\
\text { muscle } \\
\text { fibres }\end{array}$ & $\begin{array}{l}\text { Beaded } \\
\text { axons }\end{array}$ & $\begin{array}{l}\text { Spherical } \\
\text { swellings }\end{array}$ & $\begin{array}{l}\text { Coarse } \\
\text { thicken- } \\
\text { ings }\end{array}$ & $\begin{array}{l}\text { Abnormal } \\
\text { end- } \\
\text { plates }\end{array}$ & $\begin{array}{l}\text { Sprout- } \\
\text { ing }\end{array}$ & $\begin{array}{l}\text { Growth } \\
\text { cones }\end{array}$ & $\begin{array}{l}\text { Monili- } \\
\text { forme } \\
\text { tangle }\end{array}$ & $\begin{array}{l}\text { Ultra- } \\
\text { terminal } \\
\text { sprouting }\end{array}$ \\
\hline 1 & PMM & 7816 & $(+)$ & + & + & + & ++ & ++ & $t$ & & + \\
\hline 1. & PMM & 7864 & + & + & + & + & $t+$ & ++ & + & & + \\
\hline 2 & $\mathrm{KS}$ & 8159 & $(+)$ & + & + & + & ++ & ++ & & + & \\
\hline 3 & PJ & 8510 & $(+)$ & + & & & + & & & + & \\
\hline 3 & PJ & 8595 & $(+)$ & + & + & & + & $+t$ & & + & \\
\hline 4 & JO & 8625 & + & + & + & + & + & $+t$ & & + & + \\
\hline 4 & JO & 8726 & + & + & + & + & + & ++ & & + & + \\
\hline 5 & NJN & 9182 & + & + & & + & ++ & ++ & & + & \\
\hline 6 & TC & 9419 & $(+)$ & + & + & + & ++ & ++ & & + & \\
\hline 7 & GKH & 9980 & + & + & + & & ++ & $++(+)$ & & + & \\
\hline 8 & $\mathrm{PT}$ & 10110 & $(+)$ & + & + & + & ++ & ++ & & + & \\
\hline 9 & SA & 10127 & $(+)$ & + & + & + & ++ & $++(+)$ & & $t$ & + \\
\hline
\end{tabular}

nesterase method for the subneural apparatus. A third piece was removed after intravital injection of methyllene blue for visualizing the intramuscular nerve fibres (Coërs, 1952; Coërs and Woolf, 1959; Reske-Nielsen et al., 1969).

Biopsy was made on one of the first days after admission (except in case No. 2, 8 and 9). It was repeated in three of the patients after $13-25$ days of treatment, when the blood sugar level had been normal or practically normal for some time. apparatuses was increased. Some of them were transformed into large, fringed units with well-laminated and sharply limited outline (Fig. 2). Only very few showed mild degrees of degeneration, being vacuolated and pale.

The intravital methylene blue staining demonstrated bundles of nerve fibres and subterminal nerves with coarse fragmentation, irregular thickenings and spherical well-defined swellings, sometimes in rows after each other (Fig. 3). 
Many of the end-plates were bizarre or had changed to ringed and elongated forms with thin or irregularly thickened telodendrions. Sometimes the terminal expansions were seen to be small and dark, or light and plates innervating the same or two different muscle fibres. These end-plates were usually well formed, but sometimes one of them was very small. Growth cones were occasionally observed (Fig. 5).

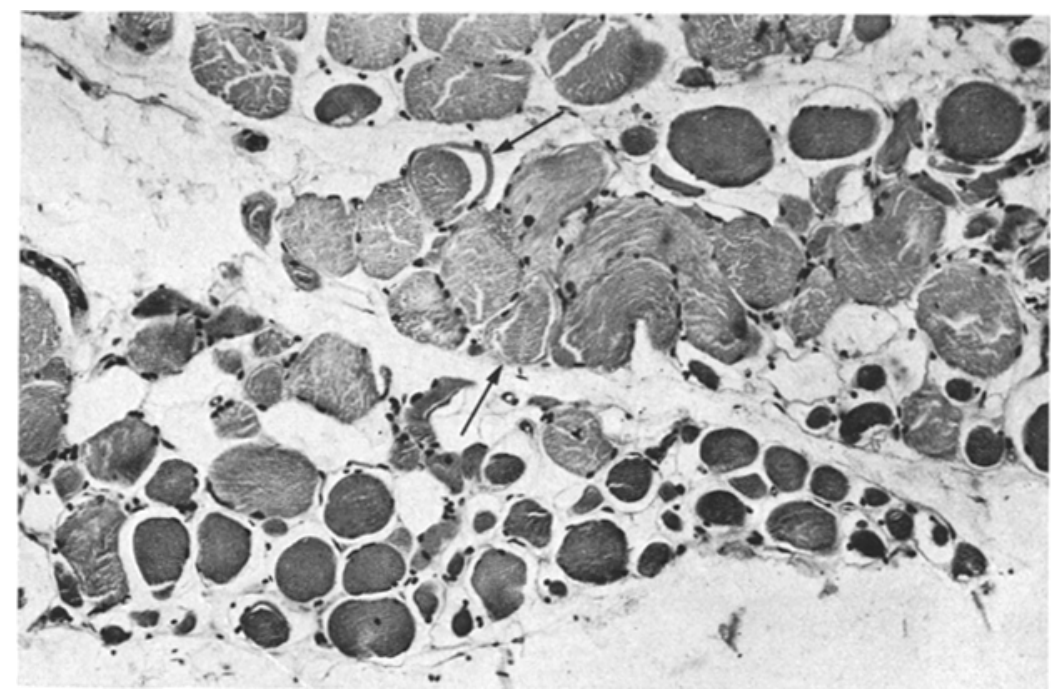

Fig. 1. Transversal section of muscle biopsy with swollen muscle fibres, ringed fibres (arrows) and neurogenic atrophy

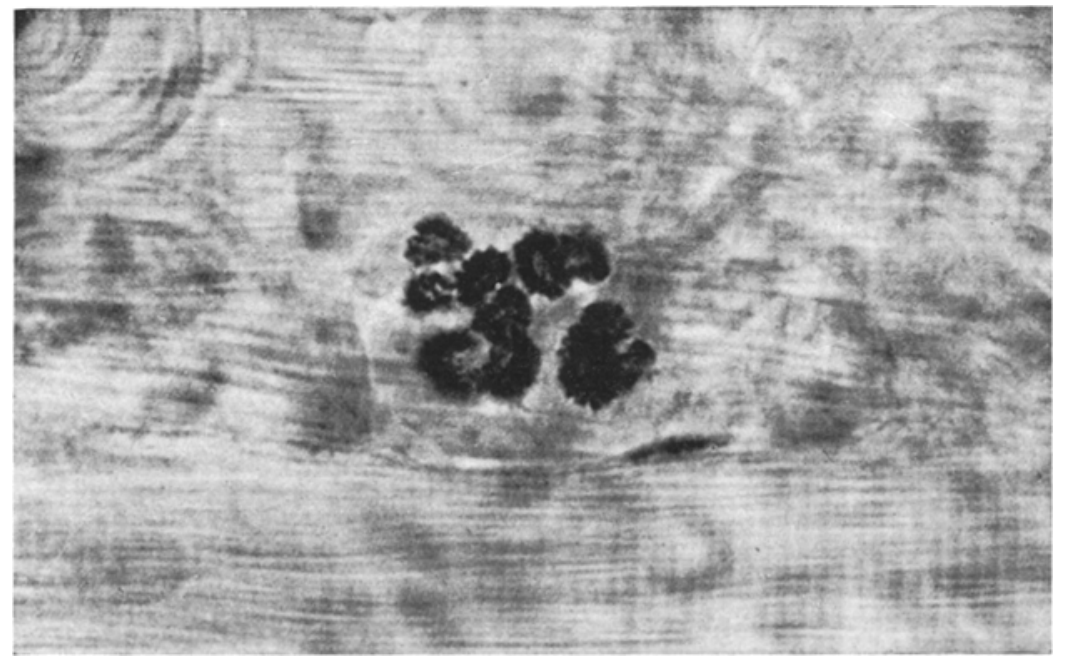

Fig. 2. Subneural apparatus with large fringed, well-laminated and sharply limited units

swollen, or granular, but the overall degree of these changes was much less pronounced than in the longterm diabetic patients described in the previous paper (Reske-Nielsen et al., 1969).

Impressive regenerative changes were also found in all the patients. Collateral ramifications along the nerve fibres were seen, sometimes a tuft of 2 to 5 , long and healthy-looking sprouts starting from one point of an axon (Fig. 4). Nearly all the nerve fibres had two end-

\section{Discussion}

Eight of the nine patients studied here had recent juvenile diabetes of the classic elinical type. One - No. 6 - was discovered accidentally and belongs to the type of "mild jurenile diabetes" described by Johansen and Lundbæk (1967). In all except one (case No. 1) the duration of diabetes was only a few weeks.

None of the patients had symptoms or signs of 
neuropathy at the clinical examination. However, determination of $\mathrm{MCV}$, EMG and vibratory perception revealed the same kind of mild abnormalities as has been described in earlier reports on a larger group of age $(p<0.02)$. On the whole, the small group of patients studied here is thus representative of the much larger groups reported by one of us (G. G.) in earlier functional studies.

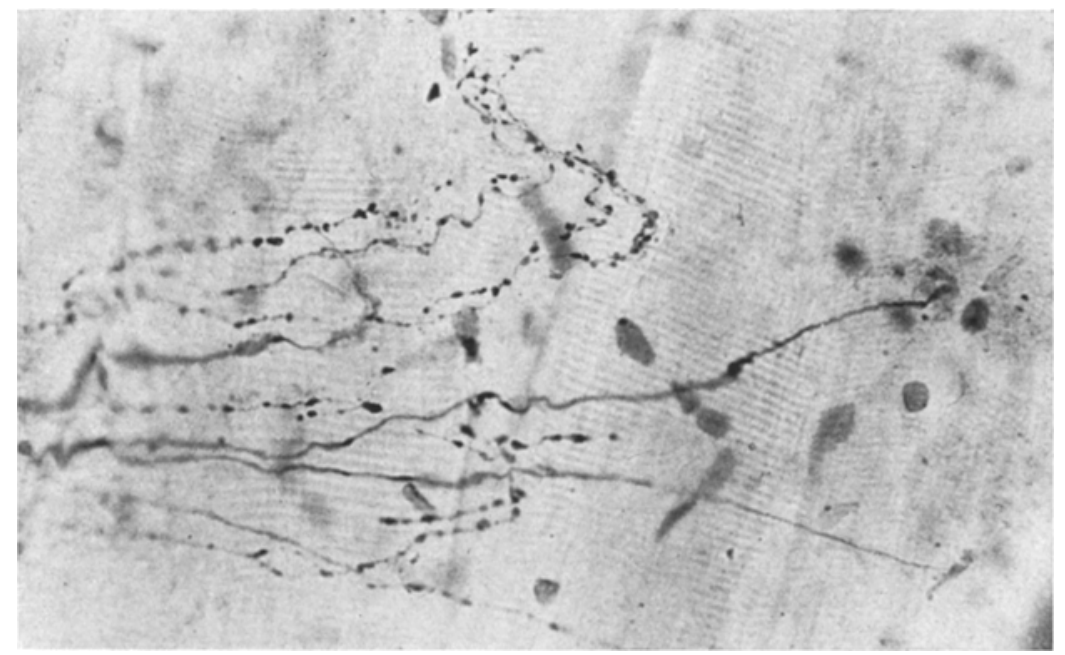

Fig. 3. Intramuscular nerve bundle with coarse fragmentation and thickenings of the axons

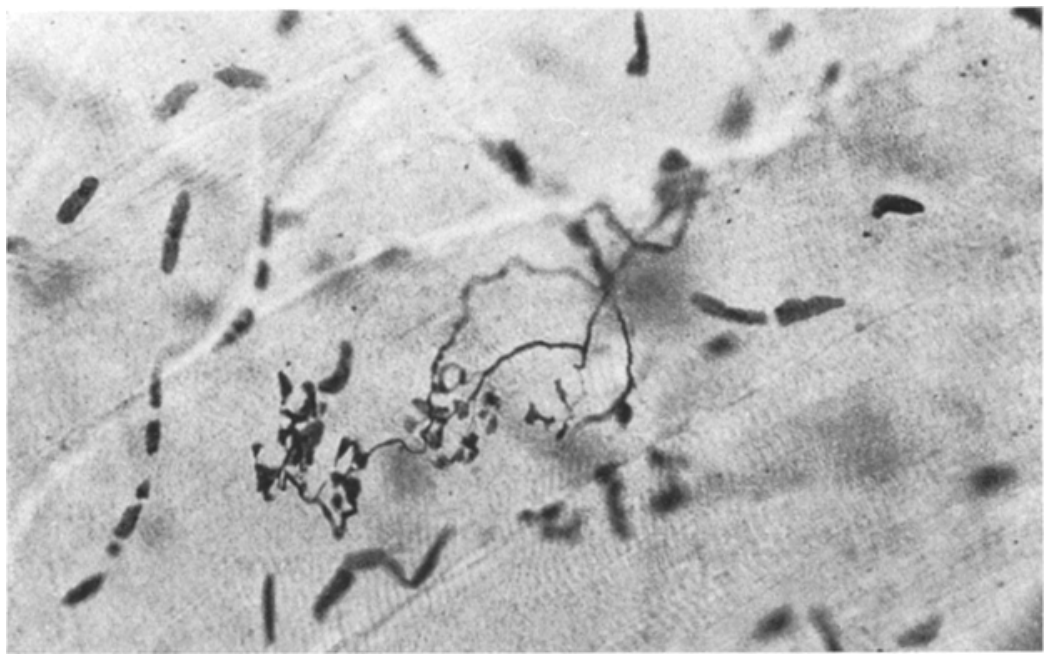

Fig. 4. Five large, slightly abnormal end plates from one axon

recent juvenile diabetics (Gregersen, $1967 ; 1968 \mathrm{a}, \mathrm{b}$, ). The average MCV (seven patients) was $45.9 \mathrm{~m} / \mathrm{s}$. In the earlier studies mentioned, the average $\mathrm{MCV}$ in young patients with a duration of diabetes of less than five years was $46.7 \mathrm{~m} / \mathrm{s}$, as against $50.8 \mathrm{~m} / \mathrm{s}$ in non-diabetics of similar age $(p<0.005)$. The average values for vibration perception threshold was $10.4 \mathrm{~V}$. This value is comparable with the average value of $10.8 \mathrm{~V}$ found earlier in juvenile diabetics with less than five years duration, as against $9.1 \mathrm{~V}$ in non-diabetics of similar
The results obtained indicate well-marked abnor malities of the terminal neuromuscular apparatus in recent juvenile diabetes. The subneural apparatus showed mild changes. The subterminal nerve fibres and the endplates showed some degree of degeneration. At the same time vigorous and healthy-looking sprouting was seen in nearly all of the cases.

This picture is in contrast to the severe degeneration of the subneural apparatus and the severely abnormal endplates seen in long-term diabetes (Reske- 
Nielsen et al., 1969). In such patients the sprouting is more pronounced than in the case of recent juvenile diabetes described in the present paper, but the sprouts are thin and obviously of poor quality. fructose in peripheral nerves of alloxan-diabetic rats has been reported by Stewart et al. (1966), as well as by Gabbay et al. (1966, 1968). Finally Eliasson and Hughes (1960) and Field and Adam (1965) have published

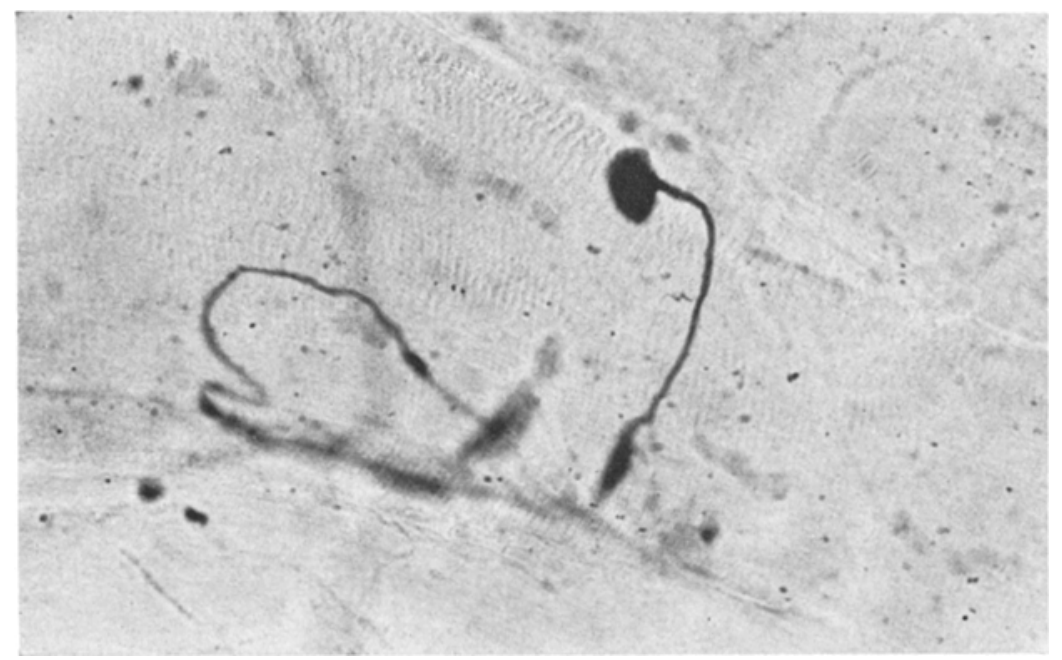

Fig. 5. An axon with a large growth cone

The predominance of healthy regenerative changes in the specimens examined in the present study may explain the lack of clinical symptoms and signs of nervous disease in our patients.

Abnormalities of peripheral axis cylinders and end organs in diabetic patients have been demonstrated earlier by Woolf and Malins (1957), Coërs and Hildebrand (1965) and by Coërs (1966). Since nearly all their patients were old, and no information available about the duration of the diabetes, these studies did not elucidate the problem of early changes. The same is true of Bischoff's electron-microscopic studies of peripheral nerves from diabetic patients (1968).

Our results may be compared, however, with those obtained in acute experimental diabetes. Hildebrand et al. (1968) reported changes of the terminal parts of the peripheral nervous system a few month after alloxanization in rats. The abnormalities described by these authors are very similar to the ones observed in recent human diabetes in the present study.

More indirectly, our results are in accordance with Bischoff's report of electron-microscopic changes of the Schwann cells a few weeks after alloxanization of hamsters (1967), and with Preston's findings (1967) of segmental myelin sheath degeneration in alloxandiabetic rats. In the last mentioned study, these changes were not found in a group of animals regulated on insulin.

Functional studies have revealed reduced motor nerve conduction velocity in alloxan-diabetic or pancreatectomized rats (Eliasson, 1964; Preston, 1967). A biochemical defect with accumulation of sorbitol and results suggesting an abnormality of the lipid metabolism of peripheral nerves in rats with alloxan dia. betes.

As stated earlier, functional studies in diabetic patients have demonstrated that early changes of nervous function are reversible (Gregersen, $1968 \mathrm{c}, \mathrm{d}$ ). In three of our patients we therefore repeated the biopsy after 13 -- 25 days of normalization of the blood sugar. However, the histological picture was the same as before treatment. It may be that a longer period of normal blood sugar is needed for the repair of the morphological changes present in the end organs of the peripheral nervous system of diabetic patients.

\section{References}

Auché, B.: Des altérations des norfs périphériques chez les diabetiques. Arch. med. exp. 2, 635-676 (1890).

Bischoff, A.: Zürich: Diabetes-colloquium 1967. To be published.

- Diabetische Neuropathie. Pathologische Anatomie, Pathophysiologie und Pathogenese auf Grund elektronenmikroskopischer Untersuchungen. Dtsch. med. Wschr. 93, 237-241 (1968).

Coërs, C.: The vital staining of muscle biopsies with methylene blue. J. Neurol. Neurosurg. Psychiat. 15, 211 $215(1952)$.

- Woolf, A. L.: The innervation of muscle. A biopsy study. Blackwell Oxford: 1959.

- Ajtération neuro-musculaire dans le diabète. Extraits du Compte rendu du Congrès de Psychiatrie et de Neurologie de Langue Française (1966).

- Hildebrand, J.: Latent neuropathy in diabetes and alcoholism. Neurology (Minneap.) 15, 19-38 (1965).

Eliasson, S. G.: Nerve conduction changes in experimental diabetes. J. clin. Invest. 43, $2353-2358$ (1964). 
- Hughes, A. H.: Cholesterol and fatty acid synthesis in diabetic nerve and spinal cord. Neurology (Minneap.) 10, $143-147(1960)$.

Fagenberg, S.-F.: Diabetic neuropathy. A clinical and histological study on the significance of vascular affections. Acta med. scand. 164, suppl. 345 (1959).

Field, R. A., Adams, L.C.: Insulin response of peripheral nerve II. Effects on lipid metabolism. Biochim. biophys. Acta 106, 474-479 (1965).

Fraser, T.R., Bruce, A.: On a case of diabetic neuritis, with a description of the post-mortem examination of the nerves and muscles. Edinburgh Med. J.42, 300-307 (1896).

Gabbay, K.H., Merola, L.O., Field, R.A.: Sorbitol pathway: Presence in nerve and cord with substrate ac cumulation in diabetes. Science 151, 209-210 (1966).

- O'Sullivan, J.B.: The sorbitol pathway: Enzyme localization and content in normal and diabetic nerve and cord. Diabetes 17, 239-243 (1968).

Gregersen, G.: Diabetic neuropathy: Influence of age, sex, metabolic control and duration of diabetes on motor conduction velocity. Neurology (Minneap.) 17 $972-980(\mathbf{1 9 6 7})$.

- Vibratory perception threshold and motor conduction velocity in diabetics and non-diabetics. Acta med. scand. 183, 61-65 (1968a).

- Latency time, maximal amplitude and electromyography in diabetic patients. Acta med. scand. 183, $55-60(1968 \mathrm{~b})$.

- A study of the peripheral nerves in diabetic subjects during ischaemia. J. Neurol. Neurosurg. Psychiat. 31, $175-181(1968 \mathrm{c})$

- Variations in motor conduction velocity produced by acute changes of the metabolic state in diabetic patients. Diabetologia 4, 273-277 (1968d).

Hildebrand, J., Joffroy, A., Graff, G., Coërs, C. : Neuromuscular changes with alloxan hyperglycemia. Electro- physiological, biochemical and histological study in rats. Arch. Neurol. 18,633-641 (1968).

Johansen, K., Lundbæk, K.: Plasma-insulin in mild juvenile diabetes. Lancet 1967 I, $1257-1259$.

Marinesco, G.: Fin Fall von diabetischer Paraplegie. Neurol. Centralblatt 22, 94 (1903).

Preston, G.M.: Peripheral neuropathy in the alloxandiabetic rat. J. Physiol. 189, 49p-50p (1967)

Reske-Nielsen, E., Lundbæk, K.: Pathological changes in the central and peripheral nervous system of young long-term diabetics II. The spinal cord and peripheral nerves. Diabetologia 4, 34-43 (1968).

- Harmsen, Aa., Hejgaard, J.J.: Modified technique of muscle biopsy. Acta path. microbiol. scand. (In press) (1969).

- Lundbæk, K., Gregersen, G., Harmsen, Aa. : Patholog. ical changes in the central and peripheral nervous system of young long-term diabetics. III. The terminal neuro-muscular apparatus. Diabetologia 6, 98-103 $(1970)$.

Steiness, I.: Influence of diabetic status on vibratory perception during ischaemia. Acta med. scand. 170, 319-338 (1961)

Stewart, M.A., Sherman, W.R., Anthony, S.: Free sugars in alloxan diabetic rat nerve. Biochem. biophys. Res. Commun. 22, 488-491 (1966).

Thomas, P.K., Lascelles, R.G.: The pathology of diabetic neuropathy. Quart. J. Med. 35, 489-509 (1966).

Woolf, A.L., Malins, J.M.: Changes in the intramuscular nerve endings in diabetic neuropathy; a biopsy study. J. Path. Bact. 73, 316-318 (1957).

E. Reske-Nielsen Kommunehospitalet Aarhus University School of Medicine Aarhus, Denmark 